\title{
Audouin's gull and the Chafarinas Islands Game Reserve
}

\author{
P. M. Bradley and P. Monaghan
}

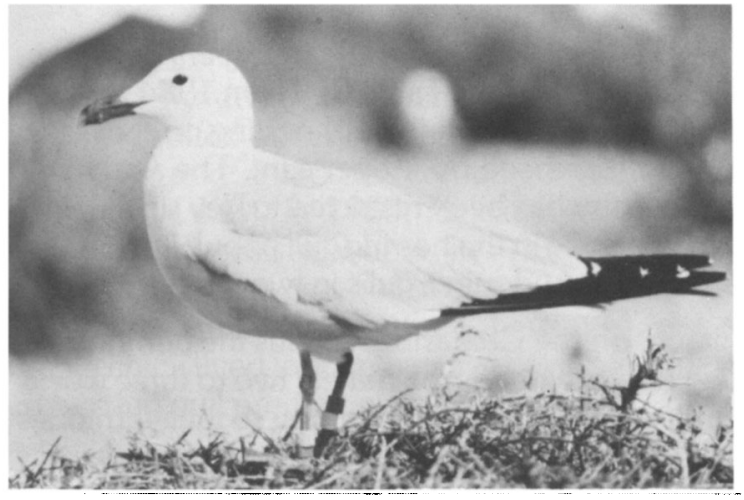

Audouin's gull, an adult with colour rings (P.M. Bradley).

The breeding population of Audouin's gull, a Red Data Book species, is endemic to the Mediterranean. Its population was estimated at 4000 pairs in 1985 , but its restricted distribution and vulnerability to disturbance and competition necessitate active conservation measures. The gull's most important breeding colony is on Rey Island in the Chafarinas group, and in 1983 a three-year study was started to discover the factors limiting the size of the colony and to formulate a management plan.

At the mouth of Moulouya River, on the Mediterranean coast of north-east Morocco, lie three small islands (Rey, Congreso and Isabel) collectively known as the Chafarinas Islands. They have been in Spanish possession since 1848, and since then a small military post has been maintained there. In 1976, the Spanish ornithologists $\mathrm{E}$. de Juana and J. Varela visited the islands. To the delight of conservationists, the islands were proven to be an important breeding site for the following species: the very rare Audouin's gull Audouin's gull and Chafarinas Islands Game Reserve

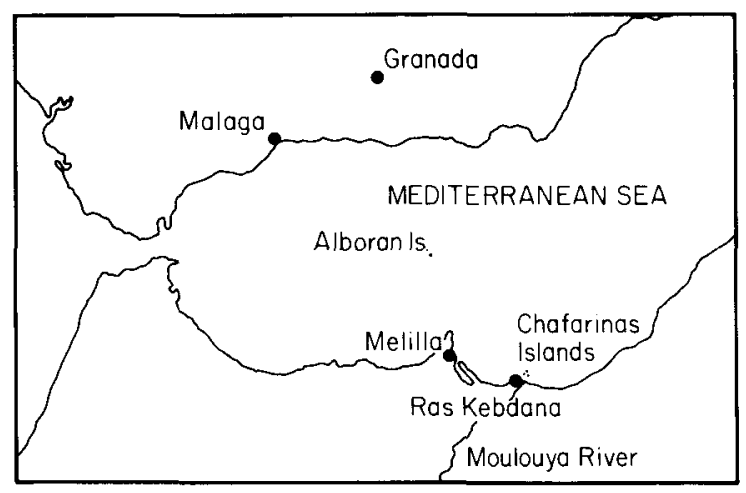

Figure 1. Location of the Chafarinas Islands.

Larus audouinii, the Mediterranean herring gull Larus argentatus michahellis, Cory's shearwater Calonectris diomedea, the osprey Pandion haliaetus, and other birds of prey. In addition, an adult Mediterranean monk seal Monachus monachus was also found to inhabit the islands' waters. Detailed studies of the breeding biology of Audouin's gull have been carried out over several years, and the importance of this Chafarinas colony is now being recognized.

\section{Audouin's gull}

Audouin's gull is an especially attractive bird. It is smaller and slimmer than the Mediterranean race of the herring gull, and its adult plumage is paler, the mantle and upper-wing being pearly-grey. The dark eyes are ringed with red. The bill is short, deep and very red, with one or two black bands and a yellow tip. The legs, in contrast with those of the yellow-legged Mediterranean herring gull, are olive-green.

Audouin's gull is listed in the IUCN Red Data 
Book (King, 1978-79) as one of the only two species of gull to be considered 'endangered'. Its breeding distribution is restricted to the Mediterranean, and the world population was estimated in 1977 at 600-800 pairs (Witt, 1977). In 1978 the WWF/IUCN initiated a project for the conservation of the species, with the objective of promoting active conservation measures for Audouin's gull throughout its range. As a result of this project, more detailed surveys were carried out and active conservation policies developed. New colonies have also been founded, and the total population was estimated to be 4000 pairs in 1985. The surveys also identified the Chafarinas Islands as the most important breeding colony; in 19852198 pairs of Audouin's gulls (55 per cent of the total breeding popuation of the species) bred there.

\section{The Chafarinas Islands study}

In view of the importance of the Chafarinas Islands to Audouin's gull, it was disturbing to discover that its numbers there had not increased since 1980 (Table 1). In 1983 a detailed threeyear study to assess the reproductive success of the gulls throughout the breeding season was initiated in an attempt to understand the factors limiting the expansion of the colony.

The islands lie only $3.5 \mathrm{~km}$ from the small Moroccan fishing village of Ras Kebdana (Figure 1). Traditionally the bird colonies in the area suffered heavily from fishermen taking eggs. Audouin's gulls do not defend their nests against humans and they nest in dense aggregations made obvious by large quantities of guano. Also, their eggs have a local reputation for being the perfect ingredient for pastry and cake-making! For many years hundreds of eggs were smuggled from the islands by Moroccans to be sold in the nearby Spanish town, Melilla. Only five years ago over 1000 eggs were taken from the Audouin's gulls on the Chafarinas (H. H. Witt in litt. to P. C. Beaubrun, 1980). In recent years landings on the colony islands have been forbidden by the Spanish army, and consequently the pillaging of eggs by humans has now been greatly reduced.

The major problem currently facing Audouin's gull is the expansion of the herring gull colony, hitherto restricted to the island of Congreso, on to 162
Table 1. Numbers of pairs of Audouin's gulls breeding on the Chafarinas Islands

\begin{tabular}{llll}
\hline Year & Rey & Congreso & Total \\
\hline 1966 & 500 & & 500 \\
1976 & 1000 & & 1000 \\
1978 & 1150 & 40 & 1190 \\
1979 & $1150-1225$ & 150 & $1300-1375$ \\
1980 & 1195 & 675 & 1870 \\
1981 & 1724 & 496 & 2220 \\
1982 & 1466 & 244 & 1710 \\
1983 & 2020 & 0 & 2020 \\
1984 & 2194 & 0 & 2194 \\
1985 & 2198 & 0 & 2198 \\
\hline
\end{tabular}

the island of Rey, where its numbers have continued to increase (Table 2). From 1984 to 1985 the number of herring gulls nesting on the island of Rey increased by 49 per cent. The Audouin's gull colony has been restricted to Rey since 1983. The increase in the herring gull population on Rey affects the Audouin's gulls in two ways.

Firstly, on the Chafarinas Islands the herring gulls begin to breed approximately two to three weeks earlier than the Audouin's gulls, so their territories are well established before the Audouin's gulls begin selecting nest sites. Audouin's gulls must therefore occupy those areas not already colonized by herring gulls, as a result of which they have been observed nesting in unsuitable sites. In 198549 pairs of Audouin's gull bred at one site that was within the splash-zone during storms, at which breeding had not been attempted in previous years. No chicks were fledged from this site.

Secondly, herring gulls have been identified as important predators of Audouin's gull eggs, chicks and adults. The extent of their predation appears to vary according to the density of the nesting Audouin's gulls. In high-density areas the Audouin's gulls can successfully deter attacking

Table 2. Number of pairs of herring gulls on the Chafarinas Islands

\begin{tabular}{lll}
\hline Year & Rey & Congreso \\
\hline 1966 & 0 & Many \\
1976 & 250 & 600 \\
1979 & 280 & 1500 \\
1983 & $450-500$ & 3514 \\
1984 & 569 & No census \\
1985 & 850 & Data not available \\
\hline
\end{tabular}

Oryx Vol 20 No 3. July 1986 


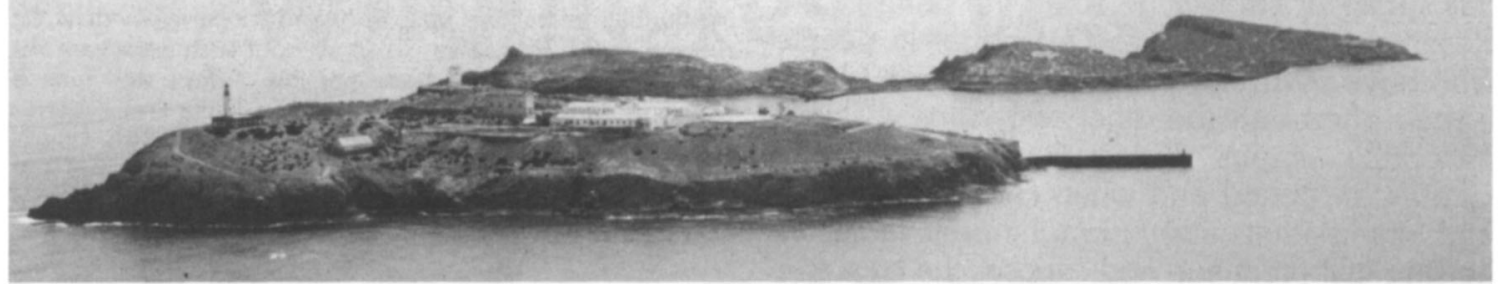

Rey, where the Audouin's gull colony nests, with the garrison island in front (P. M. Bradley).

herring gulls by communal mobbing. Where Audouin's gull nests are more widely spaced, the herring gulls can walk through the colony undeterred by diving Audouin's adults. This predation resulted in very reduced breeding success in 1984 and 1985 as compared with 1983 (Bradley, 1985). In 1985, for example, in three areas of the colony, where 407 Audouin's gulls bred (18.5 per cent of the total number of Audouin's gull nests on the Chafarinas), not a single chick lived longer than five days due largely to herring gull predation and interference.

The increase in the number of herring gulls is probably due to increased availability of food for these birds in the area. The garrison on the island Isabel empties its waste daily into the sea, and left-over food is fed to pigs in the farm. The village of Ras Kebdana has a developing fishing harbour, and increasing numbers of Spanish fishing-boats frequent the safe and duty-free harbour of the Chafarinas. Herring gulls also raid the meagre crops of the Moroccan mainland. The Audouin's gulls do not share in these benefits of man's proximity; they feed largely by catching sardines and anchovies, with the occasional grasshopper and small passerine when winds are strong, and do not scavenge (Witt et al., 1981).

In 1985 data were specifically collected with a view to the formulation of a management plan for the colony of Audouin's gulls on the Chafarinas Islands. The development of the herring gull colony on the island where the Audouin's gulls breed must be restrained (for discussion of possible methods, see Bradley, 1985). Nesting density and vegetation cover at the nest have been found to be important factors influencing the reproductive success of Audouin's gulls. Vegetation reduces predation and heat Audouin's gull and Chafarinas Islands Game Reserve stress by providing cover. At sites where there is cover, the nests are distributed around the bushes and generally nesting densities are low. As already mentioned, at low densities Audouin's gull cannot mob effectively. At high densities, where there is no vegetation, herring gulls cannot land to predate nests due to mobbing by the adults. However, reproductive output at these sites is reduced by the greater proportion of Audouin's gull chicks that are killed as a result of territorial aggression shown by neighbouring pairs of breeding Audouin's gulls. Provision of artificial vegetation may encourage nesting at an optimum density where territories are large enough to reduce intraspecific aggression but small enough to involve an effective number of Audouin's gull in mobbing at any time. It has also been recommended that a warden is employed to reduce disturbance of the colony during the breeding season. It is hoped that management of the colony will commence in 1986.

\section{Conservation status of the Chafarinas Islands}

In 1982, Spain designated the Chafarinas Islands, by a Royal Decree, as a 'Refugio de Caza' (National Game Reserve). This means, in effect, that ICONA (Instituto para la Conservacion de la Naturaleza), a part of the Spanish Ministry of Agriculture, should:

(i) control all visits and supervise scientific research on the islands,

(ii) prohibit hunting,

(iii) construct hides, fences, gates etc.,

(iv) limit fishing activities.

However, this status has in fact provided comparatively little protection for the fauna of the Chafarinas as there is no one to enforce the

163 
regulations. None of the military personnel associated with the Islands on a day-to-day basis has sufficient knowledge about the status of the Reserve or its implications. Unfortunately, people who have permission to visit the garrison island, Isabel, often visit the other two islands. This is especially serious during the Audouin's gull incubation period and when chicks are young; frightening adults away from the nests facilitates herring gull predation and exposes the eggs and chicks to the hot sun. There is a clear need for a trained conservationist to be stationed on the island during the breeding season.

Audouin's gull and the Chafarinas Islands are now a popular topic of conversation in the area, following radio broadcasts and talks given to the local community, and many people want to see them. This should be encouraged but must be supervised; precautions must be taken (e.g. observation blinds should be used and visits should not be made during the hottest times of the day) so as not to disturb the colony.

\section{Protection is necessary}

The Chafarinas Islands need protection. National and international concern for the fauna of the Chafarinas Islands may also influence the decisions of the Spanish Military with regard to the deployment of its forces on the Chafarinas. At present there is concern about proposals to replace the Spanish Infantry, Regulares No. 2, with the 'Special Forces' of the Legionaires who will spend two weeks training intensively on the islands. This could increase the level of disturbance on the colony islands if it occurs during the breeding season.

If the Chafarinas Islands were recognized by Spain as a 'Reserve Integral' and given the appropriate level of protection and management, the future of the Audouin's gull colony and a whole cross-section of Mediterranean wildlife might be safeguarded.

\section{Acknowledgments}

This study was financed by the Department of Education for
Northern Ireland, WWF, ICBP. FFPS and the BOU. The continued help and co-operation of the Spanish Military with access to the islands and during the field work has been invaluable. as has the hospitality and encouragement of the officers of the Regulares No. 2: without such assistance this study would not have been possible. Advice and help is acknowledged in particular from E. de Juana and J. Varela (Autonoma University, Madrid). Paul Goriup (ICBP). Gareth Thomas (RSPB). Jose Manuel Cabo (Melilla) and J.B. Doherty. Much gratitude is due to Jose and Cristina Cabo for the loan of their outboard motor and Zodiac.

\section{References}

Bradley. P. 1985. Interspecific competition on the Chafarinas Islands. Report to FFPS.

King. W.B. 1978-79. Red Data Book, Vol. 2. Aves. Morges, Switzerland.

Witt. H.-H., Crespo, J., de Juana, E. and Varela, J. 1981. Comparative feeding ecology of Audouin's Gull and Herring Gull. Ibis, 123, 519-526.

Witt. H.-H, 1977. Zur Biologie der Korallenmowe Larus audouinii-Brut und ernahrung. Jorn. f. Orn. 118, 134155

P. M. Bradley. The International Centre for Conservation Education. Greenfield House. Guiting Power. Glos. GL54 5TZ. UK.

P. Monaghan, Department of Zoology. The University of Glasgow. Glasgow G12 8QQ. UK.

\section{Footnote}

At the end of March. while the Chafarinas Islands were being nominated as one of the 10 key areas in the Mediterranean for the conservation of seabirds (Alghero Declaration, 1986), the presence of groups of the Special Operations Forces (Grupos de Operaciones Especiales) on the Audouin's gull colony island, Rey, was publicized in El Pais, a Spanish national newspaper, (27.3.86). As the breeding season had already commenced, CODA (Federacion Coordinadora para la Defensa da las Aves) stated that due to the combination of the factors described in this paper and the military disturbance, the survival of the Audouin's gull colony is threatened and that, probably, breeding will fail completely at this site in 1986.

CODA has suggested that the severity of the threat demands immediate action by the Spanish administration, and is asking for letters expressing concern to be sent to the Ministries of Defence and Agriculture at these addresses:

Excmo Sr Ministro de Agricultura,

Plaza de la Infanta Isabel. 1.

28071 Madrid (Spain).

Excmo Sr Ministro de Defensa.

Paseo de la Castellana. 109.

28071 Madrid (Spain). 